\title{
8. PROVENANCE OF AMAZON FAN MUDS: CONSTRAINTS FROM Nd AND Pb ISOTOPES ${ }^{1}$
}

\author{
Diane K. McDaniel, ${ }^{2}$ Scott M. McLennan, ${ }^{2}$ and Gilbert N. Hanson ${ }^{2}$
}

\begin{abstract}
Pleistocene clastic sediments of the Amazon Fan provide a record of their continental provenance and of the climatic conditions under which they were weathered and transported. We report on $\mathrm{Nd}$ and $\mathrm{Pb}$ isotopic compositions of muds from the Amazon Fan and use these data to evaluate the relative importance of the Andean highlands and cratonic lowlands as sources of sediment. Changing environmental conditions have the potential to change the relative contribution of Andean and cratonic sources to fan sediment. During the time of Amazon Fan deposition, sea-level was at a low stand, and the Andes were glaciated. It has also been postulated that the Amazon drainage basin was cooler and more arid than today. The major-element composition of Amazon Fan muds, analyzed on Leg 155, indicates that they experienced only moderate degrees of weathering, unlike many of the soils developed on the South American craton today. Nd model ages $\left(\mathrm{T}_{\mathrm{DM}}\right)$ range from 1620 to $1770 \mathrm{Ma}$. These ages are older than reported ages for Andean igneous rocks but similar to those for sediment currently being shed from the Andes highlands. Amazon Fan muds have ${ }^{206} \mathrm{~Pb} /{ }^{204} \mathrm{~Pb}$ and ${ }^{207} \mathrm{~Pb} / 204 \mathrm{~Pb}$ somewhat higher than Andean igneous rocks, indicating some component of Precambrian $\mathrm{Pb}$ in the provenance. This Precambrian component may be derived in large part from recycled sediments that exist within the Andes highlands. We conclude from geochemical compositions and $\mathrm{Nd}$ and $\mathrm{Pb}$ isotopic compositions that muds of the Amazon Fan are derived dominantly from the Andean highlands. Furthermore, during their journey to the Atlantic Ocean, they were not affected by the extreme weathering conditions such as that existing in the Amazon drainage basin today.
\end{abstract}

\section{INTRODUCTION}

Chemical and isotopic compositions of sedimentary rocks are capable of providing a record of the geologic and sedimentary history of their source not readily obtained by sedimentologic or facies analysis. In this report, we present $\mathrm{Nd}$ and $\mathrm{Pb}$ isotopic data for Amazon Fan muds obtained during Leg 155. These data, together with geochemical analyses performed during the cruise, constrain the composition and age of terrigenous sources of sediment to the Amazon Fan. Geochemical approaches to sedimentary provenance analysis are especially useful where, as on the Amazon Fan, coarse sediment is scarce, and the usefulness of conventional petrographic approaches to source characterization is thus limited. Elements that are typically mobile in the sedimentary environment (e.g., alkali and alkaline earths) can provide information about the weathering history of the source (e.g., Nesbitt and Young, 1982; Wyborn and Chappel, 1983; Sawyer, 1986; McDaniel et al., 1994a; McLennan, 1993), whereas elements that are typically conserved during sedimentary processes (e.g., the rare earth elements, [REE]) can help to constrain the composition of the original igneous source (e.g., Nathan, 1976; Andre et al., 1986; McLennan et al., 1990; McDaniel et al., 1994b). Radiogenic isotopes have the singular benefit of providing information about age domains within the source rocks. The Sm-Nd (REE's) system is robust in the sedimentary environment, and is frequently used in provenance studies to provide estimates of the mean age of mantle extraction for sedimentary sources (e.g., McCulloch and Wasserburg, 1978; Miller et al., 1986; Nelson and DePaolo, 1988; McLennan et al., 1990; Maas and McCulloch, 1981; McDaniel et al., 1994b). Whole-rock Pb isotopes have recently been applied to sedimentary provenance studies, and it appears that the $\mathrm{Pb}$ isotopic signature of the source is commonly preserved during sedimentation (McDaniel et al., 1994a; Hemming et al., 1995).

${ }^{1}$ Flood, R.D., Piper, D.J.W., Klaus, A., and Peterson, L.C. (Eds.), 1997. Proc. ODP, Sci. Results, 155: College Station, TX (Ocean Drilling Program).

${ }^{2}$ Department of Earth and Space Sciences, State University of New York at Stony Brook, Stony Brook, NY 11794-2100, U.S.A. Mcdaniel@PBisotopes.ess.sunysb.edu

\section{South American Climate Past and Present}

We are interested in evaluating how clastic sediment preserved in the Amazon Fan during Pleistocene glacial cycles reflects the evolution of terrestrial climate on the South American continent. The modern-day Amazon drainage basin is largely characterized by a warm, humid environment associated with the Amazon tropical rain forest. High chemical weathering rates, coupled with low erosion rates in the lower reaches of the basin result in soils that are depleted in cations and rich in quartz and aluminous clays over much of the area (Stallard and Edmond, 1983) as well as pure quartz sands transported by cratonic rivers (Franzinelli and Potter, 1983; Johnsson et al., 1988; Potter, 1994). In contrast, the Andes were glaciated during Pleistocene glacial stages (Clapperton, 1993; Rodbell, 1993), and some workers have proposed that these times were characterized by a cooler and more arid terrestrial environment in South America than today (e.g., Bigarella and deAndrade, 1965; Damuth and Fairbridge, 1970; Servant et al., 1993; Clapperton, 1993; Stute et al., 1995; Hansen and Rodbell, 1995). The many effects associated with climate shifts can potentially alter the relative contribution of sediment from different source regions. Variations in precipitation and temperature, alpine glaciation, and sea-level changes can potentially force changes in the sedimentary provenance, and the relative importance of these controls is not well understood.

Sediment discharged by the Amazon River during the present and past interglacial stages was deposited on the continental shelf in the form of a subaqueous delta (Milliman et al., 1975; Keuhl et al., 1982; Damuth and Flood, 1985; Nittrouer et al., 1986). During glacial-stage low stands in sea level, Amazon sediment bypassed the continental shelf and was deposited by turbidity currents onto the Amazon Fan (Damuth and Kumar, 1975; Milliman et al., 1975; Damuth, 1977). The shift in deposition to the deep-sea was due to sea level changes that occurred approximately $60 \mathrm{~m}$ below the modern sea level (Milliman et al., 1975). The Amazon Fan provides a sedimentary record for a large portion of Pleistocene glacial stages and hence the opportunity to resolve a history of sedimentary processes operating within the Amazon Basin for this period. 


\section{Source Terranes Within the Amazon Drainage Basin}

The drainage basin of the Amazon River covers approximately $6.2 \times 10^{6} \mathrm{~km}^{2}$ (Milliman and Meade, 1983) and constitutes approximately $35 \%$ of the area of South America (Fig. 1). The mouth of the Amazon River lies on the eastern, trailing-edge margin of South America, with headwaters as far west as the Phanerozoic Andean mountain belt on the western margin of the continent. The Andes mountains run the entire length of the western margin of South America (Fig. 1), and consist of Paleozoic to Holocene volcanic and plutonic rocks representing accreted island arc, backarc, and continental arc suites with varying amounts of crustal incorporation, metamorphosed basement, and thrusted sedimentary rock (James and Murcia, 1984; McCourt et al., 1984; Megard, 1984; Dalziel, 1986; Miller and Harris, 1989).

Other Amazon River tributaries originate in and flow through Precambrian rocks of the Guiana and Central Brazil shields (Fig. 1). Precambrian cratonic rocks constitute approximately $40 \%$ of exposed crust within the Amazon drainage basin (Fig. 1). Exposed basement consists primarily of Archean to Early Proterozoic high-grade gneiss and migmatite terranes and granite-greenstone belts, with some accreted Middle to Late Proterozoic mobile belts (Litherland et al., 1989; Teixeira et al., 1989; Brito Neves and Cordani, 1991; Goodwin, 1991). Pre-Pleistocene sedimentary rocks within the Amazon Basin and caught up in fold-thrust belts of the Andes may impart an inherited sedimentary signature on the composition of sediment within the modern and Pleistocene Amazon River. Geochemical and isotopic techniques do not easily resolve recycled sedimentary sources; however, with careful regard to these limitations, potential contributions can be constrained.

Although the Andes mountain chain comprises only $15 \%$ of the present-day area of the Amazon drainage basin, Gibbs (1967) estimated that greater than $80 \%$ of the dissolved solids and suspended sediment reaching the mouth of the modern Amazon River are derived from the Andes. This is not surprising as one considers the high relief of the Andes compared with the low relief of the craton. In this report, we evaluate the relative importance of Andean and cratonic sources for Pleistocene muds of the Amazon Fan and compare this to the provenance of Holocene Amazon River sediment.

\section{ANALYTICAL METHODS}

Fifteen mud samples were selected from Leg 155 sites for wholerock $\mathrm{Nd}$ - and $\mathrm{Pb}$-isotope analysis. We chose to perform isotopic analyses on aliquots of the same sample powders used for shipboard Xray fluorescence (XRF) analysis, so that we might directly compare the isotopic data with geochemical data. Toward the aim of conducting a pilot study, we selected several samples within the Upper Levee Complex (mostly younger than $40 \mathrm{ka}$; see Chapter 2 in Flood, Piper, Klaus, et al., 1995) to examine sediment deposited during the most recent sea-level cycle. To check for possible changes in provenance over longer time scales, we also spot sampled from older stratigraphic intervals, including the Middle, Lower, and Bottom Levee Complexes. Samples were chosen from levee environment muds in order to minimize effects resulting from fan sedimentation processes.

For XRF analyses on the JOIDES Resolution, approximately 20$\mathrm{cm}^{3}$ samples of mud were dried, disaggregated, rinsed in distilled water (to remove seawater), dried again, powdered in a tungsten-carbide mill, and stored in glass vials. A comprehensive explanation of XRF sample preparation and running conditions is available in the "Inorganic Geochemistry" section of the "Explanatory Notes" chapter of Flood, Piper, Klaus, et al. (1995). Data are reported in tables in the "Inorganic Geochemistry" section of the site of interest (Flood, Piper, Klaus, et al., 1995).

Nd-isotopic data were collected at Stony Brook University on unspiked samples using a Finnigan MAT Model 262 multi-collector

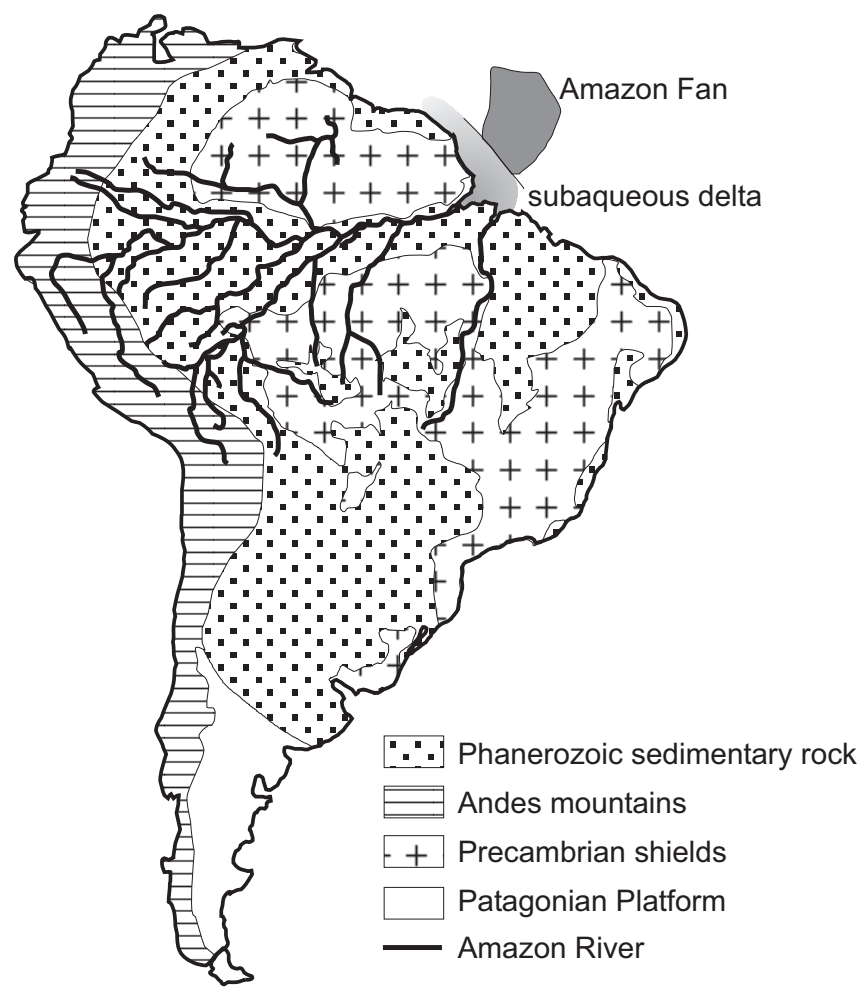

Figure 1. Map of the Amazon River drainage network, subaqueous delta, and Amazon Fan, as well as potential sources of sediment in South America. Compiled from Epenshade and Morrison (1987), Goodwin (1991), Keuhl et al. (1982), and Damuth and Kumar (1975).

thermal ionization mass spectrometer. Samples were fused with a $\mathrm{LiBO}_{2}$ flux. Rare earth element separation was achieved following a procedure similar to that presented in Stern and Hanson (1991). Nd cuts were loaded on outgassed Re side filaments and run on a double filament assembly. Ratios were collected in quadruple-dynamic mode and normalized to a ${ }^{146} \mathrm{Nd} /{ }^{144} \mathrm{Nd}=0.7219$. Accepted analyses had a ${ }^{145} \mathrm{Nd} /{ }^{144} \mathrm{Nd}$ of $0.348405 \pm 0.000009$ (all errors expressed as $2 \sigma$ ). During the time period of these analyses, a laboratory Nd standard solution yielded ${ }^{143} \mathrm{Nd} /{ }^{144} \mathrm{Nd}$ of $0.511896 \pm 0.000014(n=17)$. This compares to a La Jolla ${ }^{143} \mathrm{Nd} /{ }^{144} \mathrm{Nd}$ value of 0.511861 . In-run precision for all samples was better than 0.000007 . As a test for sample heterogeneity, the average difference between four separate sample dissolutions was $0.000013\left(<0.3 \varepsilon_{\mathrm{Nd}}\right.$ units $)$. Nd and Sm abundances were analyzed at the State University of New York at Stony Brook on a National Bureau of Standards (NBS) 6-in-radius thermal ionization mass spectrometer. Sample preparation was similar to that described for $\mathrm{Nd}$ isotope analysis. In run precision for most analyses was better than $0.1 \%$. Total analytical reproducibility for ${ }^{147} \mathrm{Sm} /{ }^{144} \mathrm{Nd}$ was approximately $0.5 \%$. Chondrite values used for normalization are: ${ }^{143} \mathrm{Nd} /{ }^{144} \mathrm{Nd}=0.512638$ and ${ }^{147} \mathrm{Sm} /{ }^{144} \mathrm{Nd}=0.1966$.

$\mathrm{Pb}$ isotopes were analyzed at Stony Brook on a NBS 12-in-radius thermal ionization mass spectrometer and on a Finnigan MAT Model 262 mass spectrometer. Whole-rock powders were twice dissolved overnight in a bomb at $220^{\circ} \mathrm{C}$, once in $\mathrm{HF}$, once in $\mathrm{HCl}$. $\mathrm{Pb}$ was separated using anion exchange resin chromatographic techniques. $\mathrm{Pb}$ was run using the $\mathrm{H}_{3} \mathrm{PO}_{4}$ /silica gel method (Cameron et al. 1969). For the NBS 12-in mass spectrometer, average ratios for 12 analyses of NBS Pb standard 982 were: ${ }^{208} \mathrm{~Pb} / 206 \mathrm{~Pb}=0.99753 \pm 0.013 \% ;{ }^{207} \mathrm{~Pb} /$ ${ }^{206} \mathrm{~Pb}=0.46650 \pm 0.006 \% ;{ }^{206} \mathrm{~Pb} /{ }^{204} \mathrm{~Pb}=36.646 \pm 0.015 \%$. Samples were corrected for a mass discrimination of $0.122 \pm 0.06 \% / \mathrm{amu}$ (atomic mass unit). For the Finnigan MAT, average ratios for 19 analyses of NBS 982 were: ${ }^{208} \mathrm{~Pb} /{ }^{206} \mathrm{~Pb}=0.99719 \pm 0.006 \%$; ${ }^{207} \mathrm{~Pb} /$ 
${ }^{206} \mathrm{~Pb}=0.46637 \pm 0.004 \%$; and ${ }^{206} \mathrm{~Pb} /{ }^{204} \mathrm{~Pb}=36.651 \pm 0.020 \%$. Samples were corrected for a mass discrimination of $0.149 \pm 0.04 \% / \mathrm{amu}$. Three sample solutions were reproduced on both machines. The average difference in ratios was $0.13 \%$ for ${ }^{206} \mathrm{~Pb} /{ }^{204} \mathrm{~Pb}$, and $\sim 0.02 \%$ for ${ }^{207} \mathrm{~Pb} /{ }^{206} \mathrm{~Pb}$ and ${ }^{208} \mathrm{~Pb} /{ }^{206} \mathrm{~Pb}$. The average difference between six separate sample dissolutions was $0.15 \%$ for ${ }^{206} \mathrm{~Pb} /{ }^{204} \mathrm{~Pb}$, and $\sim 0.08 \%$ for ${ }^{207} \mathrm{~Pb} /{ }^{206} \mathrm{~Pb}$ and ${ }^{208} \mathrm{~Pb} /{ }^{206} \mathrm{~Pb}$.

\section{RESULTS AND DISCUSSION}

\section{Geochemical Composition and Weathering History of Amazon Fan Sediment}

The major and trace element composition of 69 mud samples were analyzed by XRF during Leg 155 and are reported in Flood, Piper, Klaus, et al. (1995). The chemistries of the muds are quite uniform and typical of mud compositions. Except for one silt-rich sample, $\mathrm{SiO}_{2}$ contents for the muds ranged from 58 to $67 \mathrm{wt} \%$, and $\mathrm{Al}_{2} \mathrm{O}_{3}$ from 18 to $23 \mathrm{wt} \%$. They have about $1.4 \mathrm{wt} \% \mathrm{Na}_{2} \mathrm{O}, 3 \mathrm{wt} \% \mathrm{~K}_{2} \mathrm{O}$, and $0.8 \mathrm{wt} \% \mathrm{CaO}$. Some $\mathrm{CaO}$ abundances are considerably higher, likely due to the presence of calcium carbonate. They also tend to have relatively high $\mathrm{Fe}_{2} \mathrm{O}_{3}(\mathrm{~T})$ abundances for muds, from 6.7 to $8.6 \mathrm{wt} \%$. Rb/ Sr ratios are around 0.8 .

The geochemistry of samples from Leg 155 is compared with other relevant weathering products, rock types, and minerals on an A$\mathrm{CN}-\mathrm{K}$ plot (Fig. 2), where, in mole percent, $\mathrm{A}=\mathrm{Al}_{2} \mathrm{O}_{3}, \mathrm{CN}=\mathrm{CaO} *$ $+\mathrm{Na}_{2} \mathrm{O}$, and $\mathrm{K}=\mathrm{K}_{2} \mathrm{O}$. The diagram was developed by Nesbitt and Young (1984) to document the changes in major element chemistry induced by weathering of igneous rock. The initial work is based on thermodynamic constraints and geochemical data from weathering profiles. The diagram is intended to examine only the silicate portion of the sediment, so the samples were rinsed to remove seawater before processing. Likewise, $\mathrm{CaO}$ is corrected (and denoted $\mathrm{CaO}^{*}$ ) for $\mathrm{Ca}$ from apatite (calculated from $\mathrm{P}_{2} \mathrm{O}_{5}$ abundances). Five of the 69 muds were determined to have excess $\mathrm{CaO}$ due to calcium carbonate and are not included in Figure 2. The unplotted samples are: 155931A-1H-4, 50-55 cm; 155-931B-36X-5, 142-147 cm; 155-931B-
$38 \mathrm{X}-4,70-71 \mathrm{~cm} ; 155-936 \mathrm{~A}-43 \mathrm{X}-6,100-105 \mathrm{~cm}$; and 155-942A$5 \mathrm{H}-6,59-62 \mathrm{~cm}$.

For reference, the compositions of some minerals are plotted on Figure 2A. Igneous rocks tend to have whole-rock compositions that lie near or below the feldspar join $(\mathrm{A}=50)$ in the hatched field, with mafic rocks plotting closer to the $\mathrm{CN}$ apex than felsic rocks (Fig. 2A). During weathering, alkali and alkaline earths are released into solution, whereas alumina is preferentially retained in the weathered residue. Ca- and Na-rich mineral phases (e.g., amphiboles and plagioclase) tend to degenerate earlier than K-rich phases (e.g., orthoclase and micas). Thus, progressive weathering of an igneous rock tends to drive the composition up and to the right on this plot (arrows, Fig. $2 \mathrm{~A}$ ), so that more extremely weathered rocks will have more aluminous compositions and higher $\mathrm{K} / \mathrm{CN}$, plotting higher on the diagram. As weathering progresses and the residue becomes depleted in the $\mathrm{CN}$ component, the composition of the residue moves more parallel to the A-K axis toward the A apex (arrows, Fig. 2A). Extreme weathering produces residuals completely depleted in alkali and alkaline earths that plot at $\mathrm{A}=100$ (Fig. 2A; kaolinite and gibbsite clays, bauxite). The composition of average river sediment from rivers of different weathering regimes illustrate this trend: minimally weathered sediment (e.g., the St. Lawrence and Columbia Rivers) plots within or near the field of igneous compositions, and sediment from areas of extreme chemical weathering (e.g., the Niger and Congo Rivers) plots with $\mathrm{A} \geq 90$ (Fig. 2A, data from compilation of McLennan, 1993).

The composition of mud samples from the Amazon Fan form a linear array that is consistent with weathering trends (black field, Fig. 2B; note that Fig. 2B magnifies the upper half of Fig. 2A). Compared to compositions of world rivers, Amazon Fan muds show evidence for only intermediate degrees of weathering, with the most aluminous samples having A $<80$. Similarly, the major element composition of Amazon River suspended sediment (Martin and Meybeck, 1979; Sholkovitz and Price, 1980), Holocene Amazon subaqueous delta muds (McDaniel, unpubl. data), Orinoco River suspended sediment (Venezuela; Hirst, 1962), and Rio Paraná suspended sediment (Argentina; Martin and Meybeck, 1979) indicate moderately intense

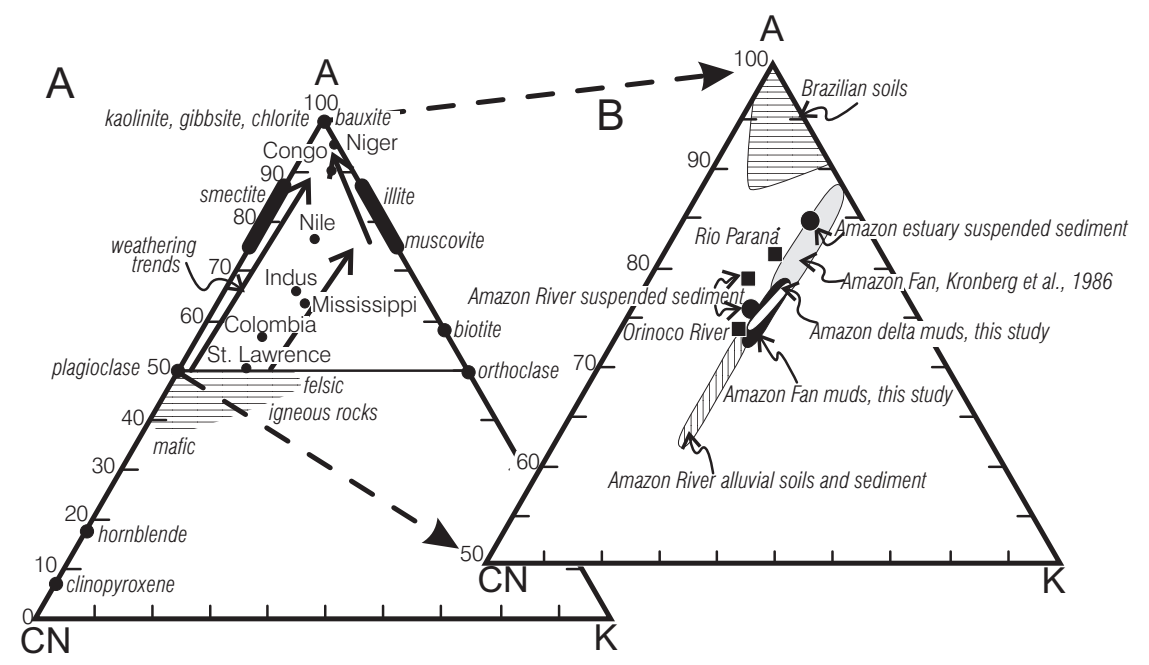

Figure 2. Plot of $\mathrm{Al}_{2} \mathrm{O}_{3}$ (A) vs. $\mathrm{CaO}^{*}+\mathrm{Na}_{2} \mathrm{O}(\mathrm{CN})$ vs. $\mathrm{K}_{2} \mathrm{O}(\mathrm{K})$ in mole percent. A. Idealized mineral compositions, and a field of typical igneous rock compositions are plotted for reference. Progressive weathering of an igneous rock results in residual compositions that follow the trend indicated by the arrows (Nesbitt and Young, 1984). Modern river sediment compositions reflect weathering intensity in the source (data from compilation of McLennan, 1993). B. Upper half of diagram with compositions of Amazon sediments. Cratonic soils have extremely weathered compositions with A>90 (Kronberg et al., 1979; Konhauser et al., 1994). Amazon Fan muds from this study show only moderate degrees of weathering compared to world rivers. Also depicted are compositions of sediment from South American rivers and various Amazon River-related sedimentary environments (data from Hirst, 1962; Martin and Meybeck, 1979; Sholkovitz and Price, 1980; Kronberg et al., 1986; Konhauser et al., 1994; and McDaniel, unpubl. data). All Amazon data fall along weathering trends that intersect the A$\mathrm{K}$ axis, and do not support a significant lateritic component in the source. 
chemical weathering in the source (Fig. 2B). Alluvial soils from around the confluence of the Rio Negro and the Amazon River (north-central Brazil) fall along a parallel and similar trend, with compositions that are on average, less weathered (Fig. 2B; Konhauser et al., 1994). The composition of suspended sediment from the Amazon estuary, however, appears to record more intense weathering (Sholkovitz and Price, 1980). Sholkovitz and Price (1980) did not analyze for $\mathrm{Na}_{2} \mathrm{O}$, therefore we estimated a value based on the average $\mathrm{CaO} / \mathrm{Na}_{2} \mathrm{O}$ of Amazon Fan sediment ( 0.6) analyzed in this study. Thus, the position of the Amazon estuary and river samples on Figure 2B should be viewed as estimates. Lateritic soil profiles from the Precambrian craton in Brazil have extremely weathered compositions (Brazilian soils field, Fig. 2B, Kronberg et al., 1979; Konhauser et al., 1994). A significant component of this material in the source of Amazon sediment should result in a mixing trend toward the high A end-member. This is not the case, however. Instead, muds from the Amazon delta and fan lie on weathering trends that intersect the A$\mathrm{K}$ axis, and show no evidence for mixing with a lateritic source. The data are consistent with either progressive degrees of weathering of a single source, or mixing of variable but intermediately weathered components. The highly weathered cratonic soils profiles that exist over a large part of the Amazon drainage basin do not appear to contribute a great proportion of the sediment being discharged to the Atlantic Ocean.

Previously published geochemical compositions have been suggestive of more extreme weathering in the source of Amazon Fan sediment (Fig. 2B; Kronberg et al., 1986). The samples from the Kronberg et al. (1986) study were taken from shallow piston cores in Wisconsin age sediment; thus it is possible that there was some difference in weathering intensity in sediment deposited around the end of the last interglacial. In any case, the reasons for the difference in geochemical compositions between Kronberg et al.'s (1986) and this study's samples require further investigation.

\section{Provenance of Amazon Fan Muds: Nd Isotopic Evidence}

Results of Nd-isotope analysis of samples from the Amazon Fan are reported in Table 1 along with $\mathrm{Nd}$ and Sm abundances and calculated isotopic parameters. Mud samples range in ${ }^{143} \mathrm{Nd} /{ }^{144} \mathrm{Nd}$ from 0.512056 to 0.512136 . Nd and $\mathrm{Sm}$ abundances are fairly uniform (39-45 ppm Nd, and 7.7-8.7 ppm Sm); ${ }^{147} \mathrm{Sm} /{ }^{144} \mathrm{Nd}$ for the samples vary even less, from 0.1182 to 0.1206 . The data are plotted in Figure 3 , which is essentially an isochron diagram. On the $y$-axis, $f_{\mathrm{Sm} / \mathrm{Nd}}$ is the fractional deviation of ${ }^{147} \mathrm{Sm} /{ }^{144} \mathrm{Nd}$ from CHUR (chondritic uniform reservoir), and $\varepsilon_{\mathrm{Nd}}$ is the deviation of the ${ }^{143} \mathrm{Nd} /{ }^{144} \mathrm{Nd}$ from CHUR in parts per $10^{4}$. Normalization results in CHUR plotting at zero for both ratios, and depleted mantle reservoirs plot at slightly positive values of each. In this manner, samples with different ages and compositions can be examined relative to a chondritic (bulk earth) reference composition near the origin. Because the power of $\mathrm{Nd}$ isotopes in sedimentary provenance studies does not rely on creating internal isochrons so much as in the comparison of different Nd reservoirs with samples of interest, we chose to present the data relative to those reservoirs.

Sedimentary processes tend to average the REE composition of the sources, and clastic sediments generally have values of $f_{\mathrm{Sm} / \mathrm{Nd}}$ of -0.4 to -0.5 . For these values, rocks evolve over time toward more negative values of $\varepsilon_{\mathrm{Nd}}$ at the rate of approximately $1 \varepsilon_{\mathrm{Nd}}$ unit per 80$100 \mathrm{Ma}$. Available data for South American cratonic rocks reflect this, with $\varepsilon_{\mathrm{Nd}}$ of between roughly -20 and -30 for $f_{\mathrm{Sm} / \mathrm{Nd}}$ of -0.4 (Fig. 3 ). For similar $f_{\mathrm{Sm} / \mathrm{Nd}}$, Andean igneous rock compositions range between -6 and $+5 \varepsilon_{\mathrm{Nd}}$ units (Fig. 3). Negative $\varepsilon_{\mathrm{Nd}}$ values for Andean rocks exist because of the incorporation of old crust into mantle melts (e.g., Miller and Harris, 1989). The composition of modern Amazon River suspended sediment (Goldstein et al., 1984) is plotted for reference. Compositions of sands from headwaters of the Amazon River in the foothills of the Andes are represented in the central field
(Fig. 3; data from Basu et al., 1990). These compositions represent an estimate of the $\mathrm{Nd}$ isotopic composition of sediment being actively eroded from the Andean highlands. This sediment has more negative values of $\varepsilon_{\mathrm{Nd}}$ than Andean igneous rocks, reflecting the incorporation of older crust from sediments caught up within Andean thrusting (Basu et al., 1990).

The total spread in Nd isotopic compositions for Amazon Fan muds is small, with values of $\varepsilon_{\mathrm{Nd}}$ varying from -11.35 to -9.79 . They lie within the field of Andean foreland sediment compositions (Fig. 3 ), indicating that the Andes is their dominant provenance. $\varepsilon_{\mathrm{Nd}}$ for Amazon Fan muds are somewhat more negative than modern Amazon River suspended sediment, an indication that there is a greater component of older Nd within them. Thus, Amazon Fan mud compositions suggest a component of Archean to Early Proterozoic cratonic $\mathrm{Nd}$ in the provenance. The amount permitted is minor, however $(<15 \%)$, and compositions also allow that they are derived nearly exclusively from the Andean highlands.

There is evidence for source variation within the sample set as well. It is evident from an expanded scale (inset, Fig. 3) that the data lie along a horizontal array with little variation in $f_{\mathrm{Sm} / \mathrm{Nd}}$ as $\varepsilon_{\mathrm{Nd}}$ changes. This corresponds to a range in depleted mantle model ages $\left(\mathrm{T}_{\mathrm{DM}}\right)$ from 1620 to $1770 \mathrm{Ma}$ (Table 1). Basu et al.'s (1990) samples were collected from different streams within the Andes foothills, and as such, reflect a range in provenance ages corresponding to the local geology of that watershed. In contrast, mixing in the Amazon River system should result in discharged sediments with compositions reflecting the average source age of all tributaries. We consider that the variations within Amazon Fan muds are geologically significant, and may be reflecting temporal changes in the average mantle extraction age of the provenance. The possibility that the variations reflect unmixing of sources by sedimentary processes operating on the fan (e.g., mineral sorting) may not be discounted. We do not believe this to be a strong control however, because the samples were selected to minimize grain-size variations, and the geochemical homogeneity of the samples supports this assessment. In any case, the range in $\mathrm{Nd}$ model ages by no means requires a cratonic contribution to the source of Amazon sediment, as this extent of variation may easily exist within the Andean highlands.

\section{Provenance of Amazon Fan Muds: Pb Isotopes}

The $\mathrm{Pb}$-isotopic composition of mud and sand samples are reported in Table 1, where it can be seen that the Pb-isotopic composition of Amazon Fan samples is fairly uniform, with ${ }^{206} \mathrm{~Pb} / 204 \mathrm{~Pb}$ compositions from 18.943 to $19.280,{ }^{207} \mathrm{~Pb} / 204 \mathrm{~Pb}$ from 15.674 to 15.728 , and ${ }^{208} \mathrm{~Pb} /{ }^{204} \mathrm{~Pb}$ from 38.910 to 39.140 . The data are plotted in Figures $4 \mathrm{~A}$ $\left({ }^{207} \mathrm{~Pb} / 204 \mathrm{~Pb}\right.$ vs. $\left.{ }^{206} \mathrm{~Pb} /{ }^{204} \mathrm{~Pb}\right)$ and $4 \mathrm{~B}\left({ }^{208} \mathrm{~Pb} / 204 \mathrm{~Pb}\right.$ vs. $\left.{ }^{206} \mathrm{~Pb} /{ }^{204} \mathrm{~Pb}\right) .{ }^{207} \mathrm{~Pb}$ and ${ }^{206} \mathrm{~Pb}$ are produced by the decay of ${ }^{235} \mathrm{U}\left(\mathrm{t}_{1 / 2}=0.7038 \times 10^{9} \mathrm{yr}\right)$ and ${ }^{238} \mathrm{U}\left(\mathrm{t}_{1 / 2}=4.468 \times 10^{9} \mathrm{yr}\right.$ ) (Steiger and Jäger, 1977), respectively. Reservoirs with a given $\mu\left({ }^{238} \mathrm{U} /{ }^{204} \mathrm{~Pb}\right)$ evolve towards higher ${ }^{207} \mathrm{~Pb} /$ ${ }^{204} \mathrm{~Pb}$ and ${ }^{206} \mathrm{~Pb} / 204 \mathrm{~Pb}$. The single-stage evolution of a $\mu=8$ reservoir is plotted on Figure $4 \mathrm{~A}$ for reference. ${ }^{208} \mathrm{~Pb}$ is the product of the decay of ${ }^{232} \mathrm{Th}\left(\mathrm{t}_{1 / 2}=14.010 \times 10^{9} \mathrm{yr}\right.$, Steiger and Jäger, 1977); thus, the ${ }^{208} \mathrm{~Pb} /{ }^{204} \mathrm{~Pb}$ composition of modern sediment can provide information on the long-term $\mathrm{Th} / \mathrm{U}$ of the source. The single-stage evolution of a $\kappa\left({ }^{232} \mathrm{Th} /{ }^{238} \mathrm{U}\right)=4(\mu=8)$ reservoir is plotted on Figure 4B for reference. The $\mathrm{Pb}$ isotope composition of the majority of Andean igneous rocks reported in the literature is encompassed by fields in Figures $4 \mathrm{~A}$ and $\mathrm{B}$, where it can be seen that the range of compositions is small. In contrast, $\mathrm{Pb}$ isotope compositions for Precambrian rocks are much more variable, and mostly outside the scale of this diagram, but they will typically have higher values of ${ }^{207} \mathrm{~Pb} / 204 \mathrm{~Pb}$ and ${ }^{206} \mathrm{~Pb} / 204 \mathrm{~Pb}$. Also plotted is the composition of modern Amazon River suspended sediment (Asmerom and Jacobsen, 1993). Sediment of the Nazca plate (Figs. 4A and B) should in large part be controlled by the average composition of sediment being eroded from the western flank of the Andes. 
Table 1. Isotopic composition of Amazon Fan muds.

\begin{tabular}{|c|c|c|c|c|c|c|c|c|c|c|}
\hline $\begin{array}{l}\text { Core, section, } \\
\text { interval }(\mathrm{cm})\end{array}$ & $\begin{array}{l}{ }^{206} \mathrm{~Pb} / \\
{ }^{204} \mathrm{~Pb}\end{array}$ & $\begin{array}{l}{ }^{207} \mathrm{~Pb} / \\
{ }^{204} \mathrm{~Pb}\end{array}$ & $\begin{array}{l}{ }^{208} \mathrm{~Pb} / \\
{ }^{204} \mathrm{~Pb}\end{array}$ & $\begin{array}{l}{ }^{143} \mathrm{Nd} / \\
{ }^{144} \mathrm{Nd}\end{array}$ & $\varepsilon_{\mathrm{Nd}}$ & ${ }^{144} \mathrm{Sm} /$ & $f_{\mathrm{Sm} / \mathrm{Nd}}$ & $\begin{array}{l}\mathrm{T}_{\mathrm{DM}} \\
(\mathrm{Ma})\end{array}$ & $\begin{array}{c}\mathrm{Nd} \\
(\mathrm{ppm})\end{array}$ & $\begin{array}{c}\mathrm{Sm} \\
(\mathrm{ppm})\end{array}$ \\
\hline $\begin{array}{l}\text { 155-931B- } \\
38 \mathrm{X}-4,70-71\end{array}$ & 18.943 & 15.715 & 39.073 & $\begin{array}{l}0.512056 \\
0.512077\end{array}$ & $\begin{array}{l}-11.35 \\
-10.94\end{array}$ & 0.1182 & -0.3990 & $\begin{array}{l}1739 \\
1705\end{array}$ & 44.68 & 8.73 \\
\hline $40 X-2,13-16$ & 19.068 & 15.700 & 39.062 & $\begin{array}{l}0.512117 \\
0.512125\end{array}$ & $\begin{array}{l}-10.16 \\
-10.01\end{array}$ & 0.1196 & -0.3917 & $\begin{array}{l}1667 \\
1654\end{array}$ & 43.09 & 8.52 \\
\hline $\begin{array}{l}155-935 \mathrm{~A}- \\
32 \mathrm{X}-2,30-34 \\
38 \mathrm{X}-3,43-48\end{array}$ & $\begin{array}{r}19.078 \\
* 19.223 \\
19.198\end{array}$ & $\begin{array}{l}15.705 \\
15.737 \\
15.718\end{array}$ & $\begin{array}{l}39.081 \\
39.131 \\
39.080\end{array}$ & $\begin{array}{l}0.512101 \\
0.512119\end{array}$ & $\begin{array}{l}-10.48 \\
-10.12\end{array}$ & $\begin{array}{l}0.1199 \\
0.1202\end{array}$ & $\begin{array}{l}-0.3902 \\
-0.3887\end{array}$ & $\begin{array}{l}1698 \\
1674\end{array}$ & $\begin{array}{l}44.41 \\
42.77\end{array}$ & $\begin{array}{l}8.80 \\
8.50\end{array}$ \\
\hline $\begin{array}{l}\text { 155-936A- } \\
\quad 41 \mathrm{X}-4,110-115\end{array}$ & $\begin{array}{r}* 19.121 \\
19.087\end{array}$ & $\begin{array}{l}15.720 \\
15.692\end{array}$ & $\begin{array}{l}39.121 \\
39.056\end{array}$ & 0.512087 & -10.75 & 0.1198 & -0.3906 & 1719 & 42.21 & 8.36 \\
\hline $6 X-2,65-68$ & $\begin{array}{r}* 19.288 \\
19.271\end{array}$ & $\begin{array}{l}15.724 \\
15.700\end{array}$ & $\begin{array}{l}39.119 \\
39.062\end{array}$ & 0.512078 & -10.92 & 0.1204 & -0.3877 & 1744 & 42.35 & 8.43 \\
\hline $\begin{array}{l}155-938 \mathrm{~A}- \\
32 \mathrm{X}-5,28-33\end{array}$ & 19.066 & 15.698 & 38.985 & $\begin{array}{l}0.512122 \\
0.512102\end{array}$ & $\begin{array}{l}-10.07 \\
-10.46\end{array}$ & 0.1199 & -0.3899 & $\begin{array}{l}1665 \\
1697\end{array}$ & 41.34 & 8.20 \\
\hline $155-940 \mathrm{~A}-$ & & & & & & & & & & \\
\hline $\begin{array}{l}\text { 2H-6, 111-114 } \\
9 \mathrm{X}-5,31-36\end{array}$ & $\begin{array}{l}19.094 \\
19.003 \\
19.012\end{array}$ & $\begin{array}{l}15.707 \\
15.711 \\
15.709\end{array}$ & $\begin{array}{l}39.136 \\
39.064 \\
39.054\end{array}$ & $\begin{array}{l}0.512056 \\
0.512080\end{array}$ & $\begin{array}{l}-11.35 \\
-10.88\end{array}$ & $\begin{array}{l}0.1200 \\
0.1199\end{array}$ & $\begin{array}{l}-0.3897 \\
-0.3903\end{array}$ & $\begin{array}{l}1772 \\
1731\end{array}$ & $\begin{array}{l}42.01 \\
43.00\end{array}$ & $\begin{array}{l}8.34 \\
8.52\end{array}$ \\
\hline $11 X-5,36-38$ & $\begin{array}{l}19.040 \\
19.027\end{array}$ & $\begin{array}{l}15.704 \\
15.713\end{array}$ & $\begin{array}{l}39.064 \\
39.071\end{array}$ & 0.512130 & -9.91 & 0.1199 & -0.3902 & 1651 & 42.40 & 8.41 \\
\hline $16 X-4,68-71$ & $\begin{array}{l}19.054 \\
19.026\end{array}$ & $\begin{array}{l}15.704 \\
15.698\end{array}$ & $\begin{array}{l}39.067 \\
39.043\end{array}$ & 0.512129 & -9.93 & 0.1200 & -0.3896 & 1655 & 40.82 & 8.10 \\
\hline $25 X-3,77-80$ & $\begin{array}{l}19.058 \\
19.114\end{array}$ & $\begin{array}{l}15.697 \\
15.731\end{array}$ & $\begin{array}{l}39.074 \\
39.205\end{array}$ & $\begin{array}{l}0.512137 \\
0.512133\end{array}$ & $\begin{array}{l}-9.77 \\
-9.85\end{array}$ & 0.1206 & -0.3868 & $\begin{array}{l}1652 \\
1658\end{array}$ & 39.28 & 7.83 \\
\hline $27 X-5,25-28$ & $\begin{array}{l}19.035 \\
19.082\end{array}$ & $\begin{array}{l}15.684 \\
15.703\end{array}$ & $\begin{array}{l}39.023 \\
39.108\end{array}$ & 0.512136 & -9.79 & 0.1189 & -0.3954 & 1624 & 40.56 & 7.97 \\
\hline $\begin{array}{l}155-942 \mathrm{~A}- \\
5 \mathrm{H}-6,59-62\end{array}$ & $\begin{array}{l}19.094 \\
19.080\end{array}$ & $\begin{array}{l}15.723 \\
15.713\end{array}$ & $\begin{array}{l}39.152 \\
39.096\end{array}$ & 0.512104 & -10.42 & 0.1191 & -0.3942 & 1679 & 39.06 & 7.69 \\
\hline $20 X-2,78-83$ & 19.089 & 15.723 & 39.127 & 0.512099 & -10.51 & 0.1195 & -0.3922 & 1694 & 42.01 & 8.30 \\
\hline
\end{tabular}

Note: $*=$ mass spectrometry replicates. All other replicates are total chemical replicates.

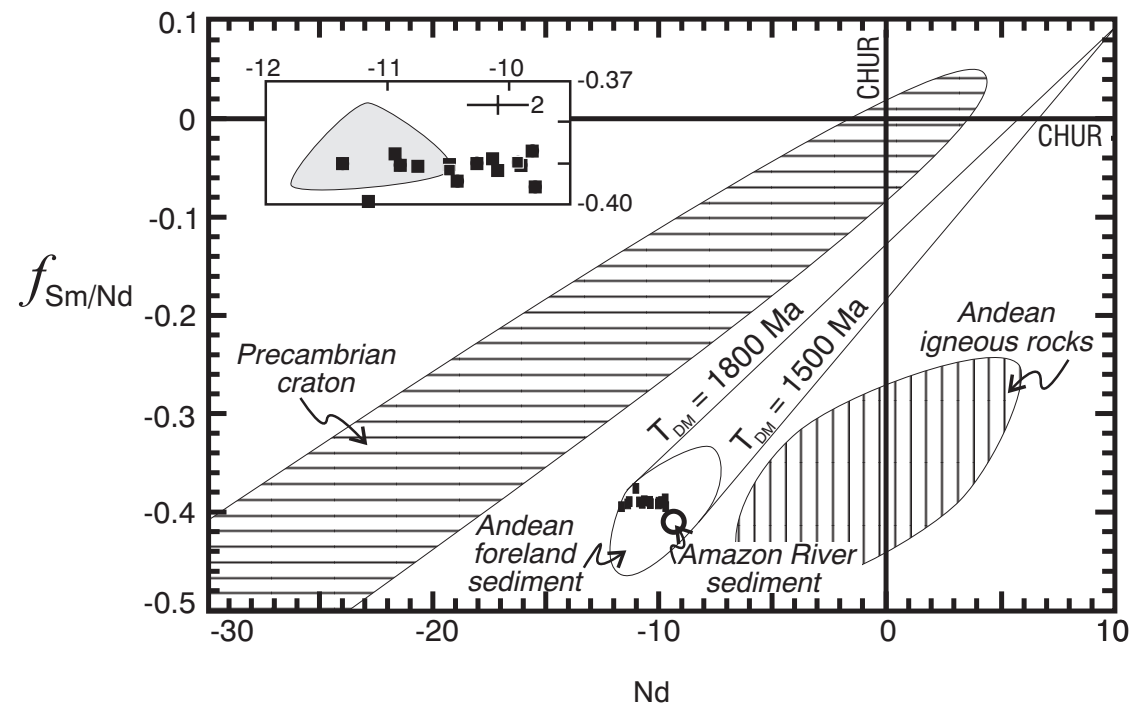

Figure 3. Plot of $f_{\mathrm{Sm} / \mathrm{Nd}}$ (fractional deviation of ${ }^{147} \mathrm{Sm} /$ ${ }^{144} \mathrm{Nd}$ from CHUR) vs. $\varepsilon_{\mathrm{Nd}}$ (fractional deviation of ${ }^{143} \mathrm{Nd} /{ }^{144} \mathrm{Nd}$ from CHUR $\left.\times 10^{4}\right)$, where samples of different ages and compositions are examined relative to a reference initial composition near the origin. Also shown are fields of published data for South American cratonic rocks and Andean igneous rocks (data from many sources), Andean foreland basin sediment (Basu et al., 1990), Amazon River sediment (Goldstein et al., 1984) and reference isochrons of 1800 and $1500 \mathrm{Ma}$. Nd isotopic composition for Amazon Fan muds (black squares) fall within the field of foreland sediment compositions, indicating that they are derived dominantly from the Andean highlands. On average, Amazon Fan muds have less negative $\varepsilon_{\mathrm{Nd}}$ (younger $\mathrm{T}_{\mathrm{DM}}$ ) than do delta muds (inset). The horizontal array defined by Amazon Fan muds describes mixing of different age sources; however, the compositions are not outside the variability within the Andean highlands.
Amazon Fan mud samples have $\mathrm{Pb}$ isotopic compositions with higher ${ }^{207} \mathrm{~Pb} /{ }^{204} \mathrm{~Pb}$ and ${ }^{206} \mathrm{~Pb} / 204 \mathrm{~Pb}$ than Andean igneous compositions, an indication of a component of Precambrian $\mathrm{Pb}$ in the source. ${ }^{235} \mathrm{U}$ has a short half-life relative to ${ }^{238} \mathrm{U}$ and is nearing extinction; thus, Phanerozoic U-decay results in the production of much more ${ }^{206} \mathrm{~Pb}$ than ${ }^{207} \mathrm{~Pb}$, and elevated ${ }^{207} \mathrm{~Pb} /{ }^{204} \mathrm{~Pb}$ compositions are diagnostic of a component of Archean $\mathrm{Pb}$. It is likely that sediment being eroded from the Andean highlands has a greater component of ancient $\mathrm{Pb}$ than average Andean igneous rocks, due to the incorporation of Precambrian basement and recycled sediments within Andean foldthrust belts. The fact that Amazon Fan sediment has ${ }^{207} \mathrm{~Pb} /{ }^{204} \mathrm{~Pb}$ and
${ }^{206} \mathrm{~Pb} /{ }^{204} \mathrm{~Pb}$ that are significantly higher than Amazon River suspended sediment as well, suggests that there may indeed be an additional cratonic component within the source. Thus, we consider that the $\mathrm{Pb}$ isotope composition of Amazon sediment is consistent with derivation dominantly from the Andes highlands, with some additional component of cratonic $\mathrm{Pb}$.

All tools employed in this study suggest that the source of Amazon Fan muds is dominated by the Andean highlands. Both Nd and $\mathrm{Pb}$ isotope compositions of the sediment indicate an Andean provenance, with a minor input from Precambrian cratonic rocks. Likewise, major element data are consistent with a source of sediment that 


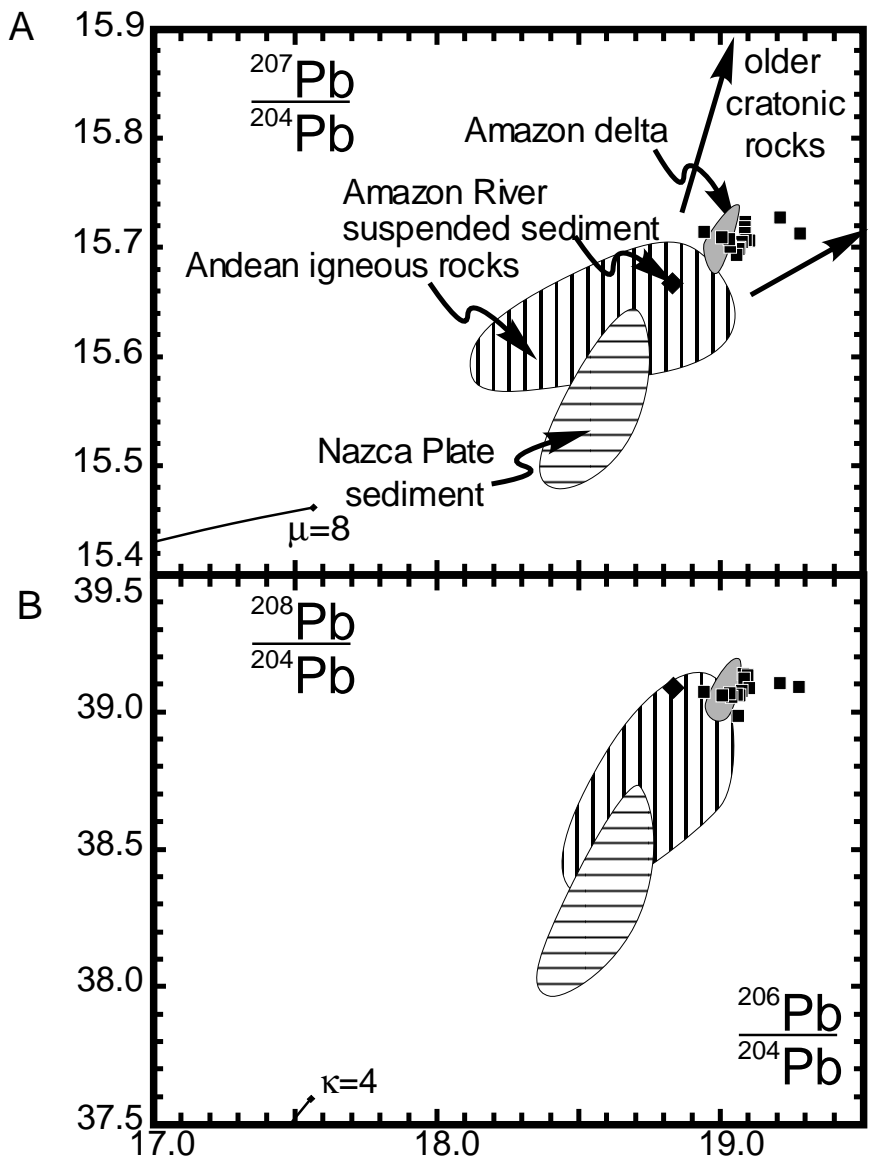

Figure 4. Plot of (A) ${ }^{207} \mathrm{~Pb} / 204 \mathrm{~Pb}$ vs. ${ }^{206} \mathrm{~Pb} /{ }^{204} \mathrm{~Pb}$ and (B) ${ }^{208} \mathrm{~Pb} /{ }^{204} \mathrm{~Pb}$ vs. ${ }^{206} \mathrm{~Pb} /{ }^{204} \mathrm{~Pb}$. The range of $\mathrm{Pb}$ isotope compositions for Andean igneous rocks is narrow (field) compared to compositions for Early Proterozoic to Archean rocks of the craton (data from many sources). Precambrian rocks have much more varied compositions, often outside the scale of this diagram, but tend to have higher ${ }^{207} \mathrm{~Pb} /{ }^{204} \mathrm{~Pb}$ and ${ }^{206} \mathrm{~Pb} /{ }^{204} \mathrm{~Pb}$ (arrows). Nazca Plate sediment compositions (Unruh and Tatsumoto, 1976; Dasch, 1981) and the composition of modern Amazon River sediment (Asmerom and Jacobsen, 1993) are also plotted for reference. Amazon Fan mud compositions have somewhat higher ${ }^{207} \mathrm{~Pb} /{ }^{204} \mathrm{~Pb}$ and ${ }^{206} \mathrm{~Pb} /{ }^{204} \mathrm{~Pb}$ than Amazon River water and Andean igneous

is only moderately weathered; there is no evidence for the lateritic soil profiles of the South American craton being a major source of sediment for the Amazon River. The mineralogic composition of Amazon Fan muds seems to agree with this interpretation. Smear slides reveal the presence of hornblende, augite, and plagioclase in the silt fractions of Amazon muds (Flood, Piper, Klaus, et al., 1995). These minerals are highly unstable in the chemical weathering environment, and their presence indicates that at least one component of the provenance of the Amazon Fan is comprised of relatively fresh igneous rocks.

It is important to recognize that the methods employed here reveal information about the provenance with respect to the element analyzed. The carriers of $\mathrm{Nd}$ and $\mathrm{Pb}$ in sediment are dominated by heavy minerals, feldspar, and clays; hence, it is these constituents that are derived from the Andes highlands. $\mathrm{Nd}$ and $\mathrm{Pb}$ isotope systematics within Amazon sediment appear to be decoupled to some degree, in that there is no clear correlation of older Nd model ages with more radiogenic $\mathrm{Pb}$. This suggests that the $\mathrm{REE}$ and $\mathrm{Pb}$ are hosted in separate minerals and are recording different aspects of the provenance. Significant sources other than Andean rocks are allowed if they do not affect the mass balance of the elements analyzed. For example, Archean and Early Proterozoic rocks of the South American craton could contribute most of the quartz to the load of the Amazon River, and this might not be detected by the techniques employed here. We observe a bimodal angularity in quartz grains within Amazon Fan sands that is similar to the quartz textures that Franzinelli and Potter (1983) described for fluvial sands of different branches of the Amazon River. This is a possible indication of different sources for Amazon Fan quartz that is worth investigating.

\section{Implications for Pleistocene South American Climate}

Comparison of the geochemical and isotopic composition of glacial-stage Amazon Fan sediment to Holocene sediment from the Amazon delta provides information for proposed models of terrestrial climate in the Amazon drainage basin during Pleistocene glaciations. Amazon Fan muds are indistinguishable from muds of the Amazon subaqueous delta on the basis of major and trace element geochemistry (Flood, Piper, Klaus, et al., 1995; McDaniel, unpubl. data). The chemical weathering of sediment deposited during the Holocene interglacial climate is no more extreme than that deposited during Pleistocene glacial stages (Fig. 2B). There is also considerable overlap between $\mathrm{Nd}$ and $\mathrm{Pb}$ isotope compositions of Amazon Fan and delta muds (Figs. 3, 4). On average however, delta muds have more negative $\varepsilon_{\mathrm{Nd}}$ (Fig. 3), and have lower ${ }^{206} \mathrm{~Pb} /{ }^{204} \mathrm{~Pb}$ and a greater variation in ${ }^{207} \mathrm{~Pb} /{ }^{204} \mathrm{~Pb}$ (Fig. 4) than do fan muds. The difference in both $\mathrm{Nd}$ and $\mathrm{Pb}$ isotopic compositions between delta and fan sediment, and Amazon River suspended sediment is significant, however, and indicates a greater cratonic contribution in the older marine delta and fan muds. Thus, $\mathrm{Nd}$ and $\mathrm{Pb}$ isotope data indicate that there may have been shifts in average source areas with Pleistocene changes in sea level.

There are several possible explanations for the geochemical and isotopic similarity of muds from the Holocene Amazon delta and glacial-stage fan. It is likely that the immediate source of sediment to Amazon Fan is subaqueous delta sediments, particularly during early stages of sea-level fall. This would suggest that during high stands in sea level, sediment is stored in the drainage basin and on the continental shelf of South America, and is transferred to Amazon Fan during glaciations, giving rise to fan compositions that are indistinguishable from delta compositions. Similarly, if the residence time of sediment in the Amazon River system is significantly longer than Pleistocene glacial-interglacial cycles (tens of ka), geochemical changes that are incurred on sedimentary compositions and/or provenance due to changing climate and sea level might be homogenized within the Amazon River system before reaching the Atlantic Ocean. The residence time, however, would not be so long as to develop a highly weathered chemical signature; the moderately weathered compositions of Amazon sediment suggests that they are on a fast course to the ocean. An additional explanation that receives further attention in the reports of Haberle and of Hoorn (both this volume) comes from palynological evidence suggesting that the difference in climate during Pleistocene glacial stages may not have been significantly less humid than today.

\section{CONCLUSIONS}

From an analysis of the geochemical and $\mathrm{Nd}$ and $\mathrm{Pb}$ isotopic composition of Amazon Fan sediment, we make the following observations:

1. Mud samples of Amazon Fan analyzed in this study have compositions that are consistent with only a moderate weathering history, and do not appear to have been significantly affected by harsh weathering conditions such as exist in the modern Amazon drainage basin. 
2. The dominant source of $\mathrm{Nd}$ and $\mathrm{Pb}$ to Amazon Fan muds is Andean. There is evidence for a cratonic source component, but it's relative importance requires further evaluation. If the craton supplies a large amount of detritus to the fan, it is not in phases that contribute significantly to the $\mathrm{Nd}$ and $\mathrm{Pb}$ budget.

3. The range in major-element compositions of Pleistocene Amazon Fan muds is indistinguishable from those of Holocene Amazon delta muds, indicating that there is no significant difference in the weathering history of sediment deposited during these two times. There is also considerable overlap in the Ndand $\mathrm{Pb}$-isotopic compositions, but minor differences suggest that there may have been some change in source with time.

\section{ACKNOWLEDGMENTS}

This work was supported by USSSP Grant \#155-20848b. The authors would like to thank the Leg 155 ODP technical staff, particularly Kazushi "Kuro" Kuroki and Wendy Autio, for assistance above and beyond the call of duty in making sure that the onboard XRF analyses were accomplished. The manuscript was improved by the helpful reviews of Jon Patchett and Wayne Nesbitt. Additional discussion of the data with Wayne Nesbitt was greatly appreciated.

\section{REFERENCES}

André, L., Deutsch, S., and Hertogen, J., 1986. Trace-element and Nd isotopes in shales as indexes of provenance and crustal growth: the Early Paleozoic from the Brabant Massif (Belgium). Chem. Geol., 57:101-115.

Asmerom, Y., and Jacobsen, S.B., 1993. The Pb isotopic evolution of the Earth: inferences from river water suspended loads. Earth Planet. Sci. Lett., 115:245-256.

Basu, A., Sharma, M., and DeCelles, P.G., 1990. Nd, Sr, isotopic provenance and trace element geochemistry of Amazonian foreland basin fluvial sands, Bolivia and Peru: implications for ensialic Andean orogeny. Earth Planet. Sci. Lett., 100:1-17.

Bigarella, J.J., and deAndrade, G.G., 1965. Contributions to the study of the Brazilian Quaternary. Spec. Pap.-Geol. Soc. Am., 84:433-451.

Cameron, A.E., Smith, D.H., and Walker, R.L., 1969. Mass spectrometry of nanogram-size samples of lead. Anal. Chem., 41:525-526.

Clapperton, C.M., 1993. Nature of environmental changes in south America at the Last Glacial Maximum. Palaeogeogr., Palaeoclimatol., and Palaeoecol., 101:189-208

Dalziel, I.W.D., 1986. Collision and Cordilleran orogenesis: an Andean perspective. In Coward, M.P., and Ries, A.C. (Eds.), Collision Tectonics. Spec. Publ.-Geol. Soc. Am., 19:389-404.

Damuth, J.E., 1977. Late Quaternary sedimentation in the western equatorial Atlantic. Geol. Soc. Am. Bull., 88:695-710.

Damuth, J.E., and Fairbridge, R.W., 1970. Equatorial Atlantic deep-sea arkosic sands and ice-age aridity in tropical South America. Geol. Soc. Am. Bull., 81:189-206.

Damuth, J.E., and Flood, R.D., 1985. Amazon fan, Atlantic Ocean. In Bouma, A.H., Normark, W.R., and Barnes, N.E. (Eds.), Submarine Fans and Related Turbidite Systems: New York (Springer), 97-106.

Damuth, J.E., and Kumar, N., 1975. Amazon Cone: morphology, sediments, age, and growth pattern. Geol. Soc. Am. Bull., 86:863-878.

Dasch, E.J., 1981. Lead isotopic composition of metalliferous sediments from the Nazca plate. Geol. Soc. Am. Mem., 154:199-209.

de Brito Neves, B.B., and Cordani, U.G., 1991. Tectonic evolution of South America during the Late Proterozoic. Precamb. Res., 53:23-40.

Epenshade, E.B., and Morrison, J.L., Sr., 1987. Goode's World Atlas (17th ed.): Chicago (Rand McNally)

Flood, R.D., Piper, D.J.W., Klaus, A., et al., 1995. Proc. ODP, Init. Repts., 155: College Station, TX (Ocean Drilling Program).

Franzinelli, E., and Potter, P.E., 1983. Petrology, geochemistry, and texture of modern river sands, Amazon River system. J. Geol., 91:23-39.

Gibbs, R.J., 1967. The geochemistry of the Amazon River system. Part I. The factors that control the salinity and the composition and concentration of the suspended solids. Geol. Soc. Am. Bull., 78:1203-1232.

Goldstein, S.L., O'Nions, R.K., and Hamilton, P.J., 1984. A Sm-Nd isotopic study of atmospheric dusts and particulates from major river systems. Earth. Planet. Sci. Lett., 70:221-236.
Goodwin, A.M., 1991. Precambrian Geology: San Diego (Academic Press). Hansen, B.C.S., and Rodbell, D.T., 1995. A late-glacial/Holocene pollen record from the eastern Andes of northern Peru. Quat. Res., 44:216-227.

Hemming, S.R., McLennan, S.M., and Hanson, G.N., 1995. Geochemical and $\mathrm{Nd} / \mathrm{Pb}$ isotopic evidence for the provenance of the Early Proterozoic Virginia Formation, Minnesota: implications for the tectonic setting of the Animike Basin. J. Geol., 103:147-168.

Hirst, D.M., 1962. The geochemistry of modern sediments from the Gulf of Paria, I. The relationship between the mineralogy and the distribution of major elements. Geochim. Cosmochim. Acta, 26:309-334.

James, D.E., and Murcia, L.A., 1984. Crustal contamination in northern Andean volcanics. J. Geol. Soc. London, 141:823-830.

Johnsson, M.J., Stallard, R.F., and Meade, R.H., 1988. First-cycle quartz arenites in the Orinoco River basin, Venezuela and Columbia. J. Geol., 96:263-277.

Konhauser, K.O., Fyfe, W.F., and Kronberg, B.I., 1994. Multi-element chemistry of some Amazonian waters and soils. Chem. Geol., 111:155-175.

Kronberg, B.I., Fyfe, W.S., Leonardos, O.H., Jr., and Santos, A.M., 1979. The chemistry of some Brazilian soils: element mobility during intense weathering. Chem. Geol., 24:211-229.

Kronberg, B.I., Nesbitt, H.W., and Lam, W.W., 1986. Upper Pleistocene Amazon deep-sea fan muds reflect intense chemical weathering of their mountainous source lands. Chem. Geol., 54:283-294.

Kuehl, S.A., Nittrouer, C.A., and DeMaster, D.J., 1982. Modern sediment accumulation and strata formation on the Amazon continental shelf. Mar. Geol., 49:279-300.

Litherland, M., Annells, R.N., Darbyshire, D.P.F., Fletcher, C.J.N., Hawkins, M.P., Klinck, B.A., Mitchell, E.A., O'Connor, P.E.J., Pitfield, P.E.J., Power, G., and Webb, B.C., 1989. The Proterozoic of eastern Bolivia and its relationship to the Andean mobile belt. Precambrian. Res., 43:157174.

Maas, R., and McCulloch, M.T., 1981. The provenance of Archean clastic metasediments in the Narryer gneiss complex, Western Australia: trace element geochemistry, $\mathrm{Nd}$ isotopes, and $\mathrm{U}-\mathrm{Pb}$ ages for detrital zircons. Geochim. Cosmochim. Acta, 55:1915-1932.

Martin, J.M., and Meybeck, M., 1979. Elemental mass-balance of material carried by major world rivers. Mar. Chem., 7:173-206.

McCourt, W.J., Aspden, J.A., and Brook, M., 1984. New geological and geochronological data from the Colombian Andes: continental growth by multiple accretion J. Geol. Soc. London, 141:831-845.

McCulloch, M.T., and Wasserburg, G.J., 1978. Sm-Nd and Rb-Sr chronology of continental crust formation. Science, 200:1003-1011.

McDaniel, D.K., Hemming, S.R., McLennan, S.M., and Hanson, G.N., 1994a. Petrographic, geochemical, and isotopic constraints on the provenance of the Early Proterozoic Chelmsford Formation, Sudbury Basin, Ontario. J. Sediment. Res., A64:362-372.

1994b. Resetting of neodymium isotopes and redistribution of REEs during sedimentary processes: the Early Proterozoic Chelmsford Formation, Sudbury Basin, Ontario, Canada. Geochim. Cosmochim. Acta, 58:931-941.

McLennan, S.M., 1993. Weathering and global denudation. J. Geol., 101:295-303.

McLennan, S.M., Taylor, S.R., McCulloch, M.T., and Maynard, J.B., 1990. Geochemical and Nd-Sr isotopic composition of deep-sea turbidites: crustal evolution and plate tectonic associations. Geochim. Cosmochim. Acta, 54:2015-2050.

Megard, F., 1984. The Andean orogenic period and its major structures in central and northern Peru. J. Geol. Soc. London, 141:893-900.

Miller, J.F., and Harris, N.B.W., 1989. Evolution of continental crust in the Central Andes: constraints from $\mathrm{Nd}$ isotope systematics. Geology, 17:615-617.

Miller, R.G., O'Nions, R.K., Hamilton, P.J., and Welin, E., 1986. Crustal residence ages of clastic sediments, orogeny and crustal evolution. Chem. Geol., 57:87-99.

Milliman, J.D., and Meade, R.H., 1983. World wide delivery of river sediment to the oceans. J. Geol., 91:1-21.

Milliman, J.D., Summerhayes, C.P., and Barretto, H.T., 1975. Quaternary sedimentation on the Amazon continental margin: a model. Geol. Soc. Am. Bull., 86:610-614.

Nathan, S., 1976. Geochemistry of the Greenland Group (Early Ordovician), New Zealand. N. Z. J. Geol. Geophys., 19:683-706.

Nelson, B.K., and DePaolo, D.J., 1988. Comparison of isotopic and petrographic provenance indicators in sediments from Tertiary continental basins of New Mexico. J. Sediment. Petrol., 58:348-357. 
Nesbitt, H.W., and Young, G.M., 1982. Early Proterozoic climates and plate motions inferred from major element chemistry of lutites. Nature, 299:715-717.

, G.M., 1984. Prediction of some weathering trends of plutonic and volcanic rocks based on thermodynamics and kinetic considerations. Geochim. Cosmochim. Acta, 48:1523-1534.

Nittrouer, C.A., Kuehl, S.A., DeMaster, D.J., and Kowsmann, R.O., 1986. The deltaic nature of Amazon shelf sedimentation. Geol. Soc. Am. Bull., 97:444-458.

Potter, P.E., 1994. Modern sands of South America: composition, provenance and global significance. Geol. Rundsch., 83:212-232.

Rodbell, D.T., 1993. Subdivision of Late Pleistocene moraines in the Cordillera Blanca, Peru, based on rock-weathering features, soils, and radiocarbon dates. Quat. Res., 39:133-143.

Sawyer, E.W., 1986. The influence of source rock type, chemical weathering and sorting on the geochemistry of clastic sediments from the Quetico metasedimentary belt, Superior Province, Canada. Chem. Geol., 55:7795.

Servant, M., Maley, J., Turcq, B., Absy, M., Brenac, P., Fournier, M., and Ledru, M., 1993. Tropical forest changes during the Late Quaternary in African and South American lowlands. Global Planet. Change, 7:25-40.

Sholkovitz, E.R., and Price, N.B., 1980. The major-element chemistry of suspended matter in the Amazon Estuary. Geochim. Cosmochim. Acta, 44:163-171.

Stallard, R.F., and Edmond, J.M., 1983. Geochemistry of the Amazon, 2: the influence of geology and weathering environment on the dissolved load. J. Geophys. Res., 88:9671-9688.
Steiger, R.H., and Jäger, E., 1977. Subcommission on geochronology: convention on the use of decay constants in geo- and cosmochronology. Earth Planet. Sci. Lett., 36:359-362.

Stern, R.A., and Hansen, G.N., 1991. Archean high-Mg granodiorite: a derivative of light rare earth element-enriched monzodiorite of mantle origin. J. Petrol., 32:201-238.

Stute, M., Forster, M., Frischkorn, H., Serejo, A., Clark, J.F., Schlosser, P., Broecker, W.S., and Bonani, G., 1995. Cooling of tropical Brazil $\left(5^{\circ} \mathrm{C}\right)$ during the last glacial maximum. Science, 269:379-383.

Teixeira, W., Tassinari, C.C.G., Cordani, U.G., and Kawashita, K., 1989. A review of the geochronology of the Amazonian craton: tectonic implications. Precamb. Res., 42:213-227.

Unruh, D.M., and Tatsumoto, M., 1976. Lead isotopic composition and uranium, thorium, and lead concentrations in sediments and basalts from the Nazca plate. In Yeats, R.S., Hart, S.R., et al., Init. Repts. DSDP, 34: Washington (U. S. Govt. Printing Office), 341-347.

Wyborn, L.A.I., and Chappel, B.W., 1983. Chemistry of the Ordovician and Silurian greywackes of the Snowy Mountains, southeastern Australia: an example of chemical evolution of sediments with time. Chem. Geol., 319:81-92.

Date of initial receipt: 20 November 1995

Date of acceptance: 10 April 1996

Ms 155SR-207 